\title{
Analyzing the Implementation of Student Evaluation Approach for Lecturer Performance Evaluation at Manado State Polytechnic
}

\author{
Selfy Manueke*, Elvie J. Weku, Meiske Manopo \\ Business Administration Department \\ Manado State Polytechnic \\ Manado, Indonesia \\ *self22r@gmail.com
}

\begin{abstract}
Evaluation of lecturer performance, which is done by students, is one of the ways used by Manado State Polytechnic to measure customer satisfaction on lecturer performance in conducting teaching and learning process. Evaluation of lecturer performance through Student Evaluation approach has been started since Year 2009, but to know the achievement of appraisal of lecturer performance, it is necessary to conduct research. This study aims to analyze the implementation of Student Evaluation Approach for lecturer performance evaluation at Manado State Polytechnic and optimizing the evaluation approach by developing an application based online. The method used for data collection is the qualitative method with Semi-Structured Interview where the data is collected by interviewing all parties involved in the implementation of lecturer's performance evaluation. After data is collected, grouped and coded, the data is analyzed and interpreted, and then it is coded into application system. The results of this study are expected to be used by every department in Manado State Polytechnic to facilitate and to ease the measurement of lecturer performance every semester.
\end{abstract}

\section{Keywords-lecturer performance evaluation, analyzing}

\section{INTRODUCTION}

Evaluation of lecturer performance is one of the ways used by Manado State Polytechnic to measure customer's satisfaction to service and lecturer's performance in conducting teaching and learning process. Evaluation of Lecturer's Performance is done by Manado State Polytechnic through Center for Learning and Quality Assurance, where the Center issues lecturer performance evaluation form and distributes it to each study program. The Study Program Coordinator further distributes the form to all students and students give manual responses / assessments of the contents of the form according to what they experience and feel during the one-semester learning process. Because the responses / assessments are done manually, sometimes the students' judgments are less objective in which the students jointly provide their judgment, or sometimes because the lecturers are in the classroom so the students do not provide the assessments as they feel or the students feel afraid of giving real judgments.
Evaluation is the implementation of a general assessment based on values [1], can also be seen as one of the institutional ways to improve the condition of their institutions [2]. In higher education institutions, evaluation is an important process for educational institutions in carrying out their programs [3], conducted by a person or group of persons designated by the authorities, either internally or externally [4]. As it is known that higher education institutions are obliged to organize 3 (three) main activities, namely Education, Research and Community Service, but with regard to this research, education or teaching activities become the focus of discussion. Evaluation of the teaching activity includes the preparation of the materials, the ability to communicate materials or lessons to the students, and the ability to assess and the ability to report student learning outcomes.

Each educational institution has its purpose in carrying out an evaluation activity. An institution will conduct an evaluation for several reasons such as development, improvement, measurement, and assessment [5]. Furthermore, evaluation may be undertaken for the purpose of maintaining and improving the quality of educational services [4], and as one way to increase the productivity of universities [6].

Furthermore, in particular, evaluation of teaching may differ between educational institutions. Some institutions may use evaluation for professional development purposes, such as developing new teacher training programs or courses. Other institutions undertake evaluation of education/ teaching for the purpose of improving education such as improving the quality of teaching, or a study program, improvement of learning outcomes, or improvement in remuneration [7-9]. Thus, the purpose of evaluation of education/teaching varies depending on the needs and desires of the institution. To achieve the objectives as mentioned above, evaluation should be conducted by people who are capable and eligible to provide objective information, including students, peers and superiors. In relation to this research, the information sources that are considered objective in providing information or evaluation for educational/teaching teachers/lecturers are students.

Student evaluation is one of the approaches used by higher education institutions in obtaining information about the 
performance of lecturers. According to some experts, the "Student Evaluation" approach in lecturer performance evaluation activities is very popular because it is widely found that through this approach, the institution can obtain objective information about the performance of its academic staff [9-15]. Furthermore, student evaluation is an independent evaluation conducted to gain feedback from students on the performance of their lecturers [16] and to ensure the quality of teaching in higher education institutions [17].

In countries such as Australia, the "Student Evaluation" approach is used by most universities to evaluate the performance of its academic staff as well as its educational programs [9,18-21]. Thus, in Australia, students are deeply involved in the evaluation process to provide responses/perceptions of the learning process and educational programs run by its teachers. This evaluation is important for the institution for several reasons, both internal and external. Internally, student evaluation can provide information to the institution about the performance of its academic staff and also help the institution to identify gaps between expected performance and current performance conditions so that immediate action can be taken to improve the learning process as well as its educational programs. Furthermore, student input can contribute to decision making to promote lecturers.

In the United States, student evaluation is widely used by educational institutions and universities [7,21] where standardized student evaluation is made by each faculty. Some institutions tend to use instruments where students are asked to respond to sections such as demographic information, educational and instructor programs, educational value, and teaching skills. For example: The Faculty of Education at Southern Research University has standardized student evaluation form with 36 items and is used by 9 (Nine) majors at the faculty [7]. Most Canadian educational institutions apply student evaluation by requesting responses to all students enrolled in a particular course by ranking their chosen courses $[9,22]$. Beran et al. suggests that the results of the student evaluation differ depending on the characteristics of the course, the year of the program and the status of the student enrolled during the period [22].

Student evaluation is also used by educational institutions in Israel [23]. For example, Jordan Valley Regional educational institutions conduct assessments of courses and learning with a student evaluation approach with 12 items in one paper, i.e. students are required to evaluate outlines of educational programs, educational program objectives, references used, learning outcomes and assessments. In relation to the assessment of lecturers' teaching, students are asked to respond to questions about communication skills and lecturers' abilities. The same is in the United Kingdom and the Netherlands. Some institutions have developed standardized teaching packages where student responses are included in the evaluation process.

In Indonesia, most institutions use student evaluation to obtain information on lecturers' performance, such as those conducted by the Center for Learning and Quality Assurance at Manado State Polytechnic. As an application of student evaluation, each institution can create its own form for student evaluation in evaluating lecturers' performance.
Based on the above background, the research team is interested in conducting research on analyzing the implementation of "Student Evaluation Approach "for lecturer performance evaluation at Manado State Polytechnic, and optimizing the evaluation approach by developing an application system based online, to contribute to the effectiveness of lecturer performance evaluation through student evaluation approach and the process of quality improvement on learning at Manado State Polytechnic.

\section{RESEARCH METHODOLOGY}

The method used for data collection is the qualitative method with Semi-Structured Interview where the data is collected by interviewing all parties involved in the implementation of lecturer's performance evaluation. Semistructured interviews allow the researcher the flexibility to follow a particular line of enquiry that may not have been expected and thus permit the collection of richer data [24]. The participants that are involved in this research comprise the Head of Centre Learning and Quality Assurance as well as 19 Study Program Coordinators at Manado State Polytechnic. After data is collected, grouped and coded, then the data is analyzed and interpreted. The focuses of this research is to analyze the implementation of student evaluation approach which is done manually and to optimize the implementation of student evaluation approach through developing the application system based online.

\section{DISCUSSION}

\section{A. Analyzing the Current Student Evaluation Approach Implemented Manually in Manado State Polytechnic}

1) Issuing the student evaluation form: From the SemiStructured Interview, it is found that to evaluate the lecturer performance, the Head of Learning Centre and Quality Assurance of Manado State Polytechnic is responsible to issue a Lecturer Performance Form and then it distributes to departments. Head of departments, then, distribute it to all study programs coordinators. Below is the form of lecturer performance filled by students.

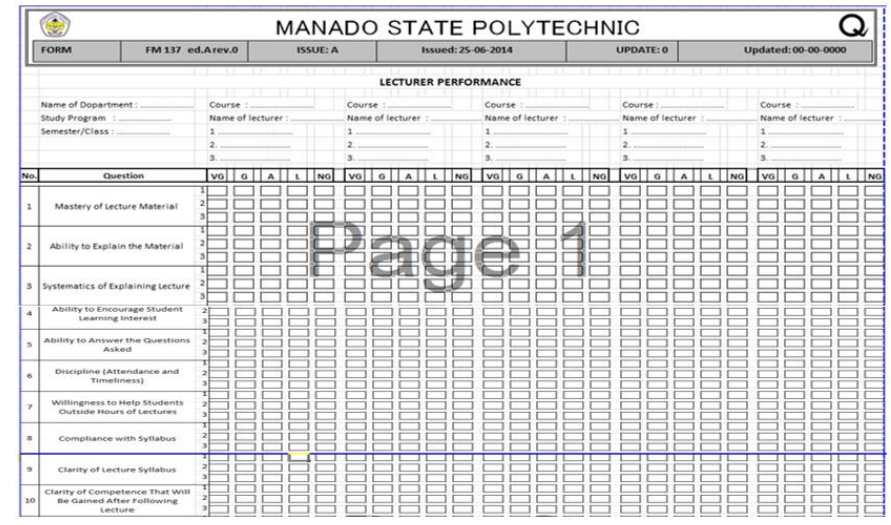

Fig. 1. Form of lecturer performance filled by students. 
Figure 1 shows that in evaluating lecturer performance in teaching activities, students are required to answer 11 items, such as:

- Mastery of Lecture Material,

- Ability to Explain the Material,

- Systematics of Explaining Lecture,

- Ability to Encourage Student Learning Interest,

- Ability to Answer the Questions Asked,

- Discipline (Attendance and Timeliness),

- Willingness to Help Students Outside Hours of Lectures,

- Compliance with Syllabus,

- Clarity of Lecture Syllabus,

- Clarity of Competence That Will Be Gained After Following Lecture, and

- Assessment Procedures.

The above items can be categorized into four sections, such as teacher ability skills (items 1 to 5,7 ), teacher discipline (item 6), syllabus used (items 8-10), and assessment procedures (item 11). It uses Likert scale, such as very good, good, average, less, very less. These assessment items are almost agreed with assessment items used by other institutions especially in items lecturer ability skills [21].

2) Distribution of the student evaluation form: According to the interviews, the distribution of the form to students is conducted at the end of the semester. The study program coordinator executes it to all students in each class assisting by administrative staff in each study program. Students are asked to give score to every item in the form. After filling the form, then, the administrative staff collects the forms from the students.

3) The effectiveness of using student evaluation: Based on the result of interviews, the effectiveness of using this manual form is less effective because some disturbance exist like students do not say the truth due to they are afraid to their lecturers. Students work together when filling the form.

4) Recapitulation of student evaluation: The forms that are collected by the administrative staff are submitted to study program coordinator. Study program coordinator is responsible to count the results of lecturer performance. Due to there are many classes, the study program coordinator is assisted by the administrative staff in counting the results of lecturer performance.

5) Barrier of conducting the student evaluation: In conducting the student evaluation approach, some barriers are happened, such as the forms are not returned completely. Students are not seriously fill the form, therefore, it is difficult to judge the lecturer performance whether he/she performs well or not.
6) Results of lecturer performance: The results of lecturer performance are kept in study program office and it is only reported by the study program coordinator to the Head of department and to the Head of Learning Centre and Quality Assurance. It is not informed to each lecturer; therefore, each lecturer never knows his/her performance in class. If each lecturer knows about his/her performance, perhaps he/she will make improvement or increase his/her performance. Thus, Head of Department and Study Program Coordinator are difficult to make judgment to the lecturer when his/her performance is not satisfied. According to the interviews, lecturers who did not perform well in teaching, the management of department or study program will not involve them in additional activities in department level and they will not be recommended in additional activities in Polytechnic level.

7) Follow up of the evaluation results: The followed up of the results of lecturer performance is not yet applied, such as reward and punishment, but it is expected to be applied in order to improve the quality of education especially learning processes.

\section{B. Optimizing the Implementation of Student Evaluation Approach Through Application System Based Online}

Student evaluation approach based online can be a solution to solve the problem of implementing the evaluation of lecturer performance and optimizing the student evaluation approach used in Manado State Polytechnic. Following is the steps of using the system.

1) Login to the system: All parties are given a login form as shown in Figure 2 and 3 below.

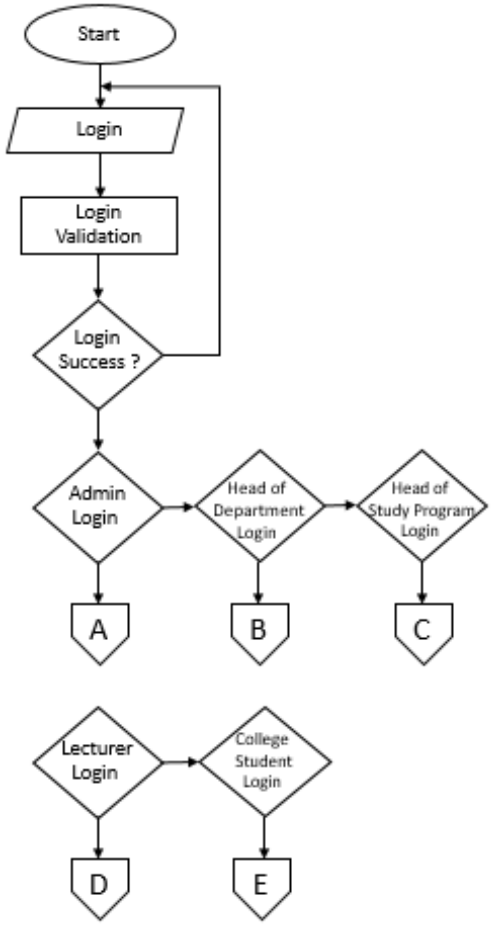

Fig. 2. Login flowchart. 


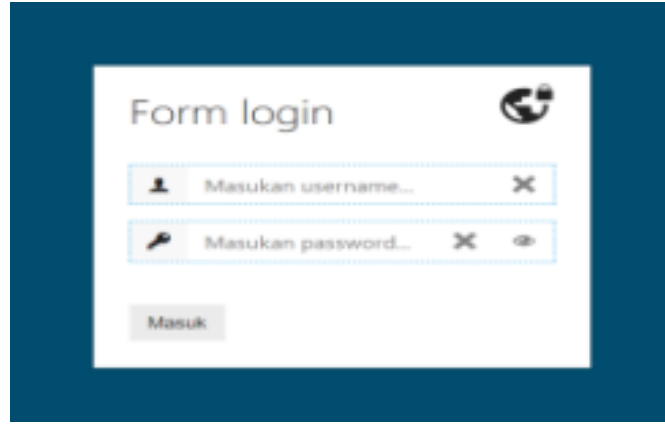

Fig. 3. Login form to the system.

There are several parties involved and have rights to access when implementing the application system, administrator, student, lecturer, head of department and study program coordinator. All parties can login to the application system using the login access given by the administrator of the system.

2) Administrator: In this page, the study program administrator can manage all data in the system, such as department data, study program data, courses data, semester/class data, lecturers' data and students' data. This page also allows the administrator to activate or inactivate the editing of the questionnaire/form to limit the time of making data changes by students in the system. Below is the figure 4 shown the front page of dashboard of study program administrator.

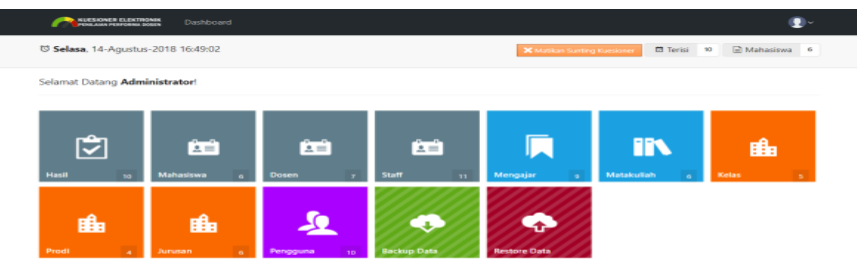

Fig. 4. The front page of dashboard of study program staff.

3) Student: Following Figure shows how is student's access to the form (questionnaire) of lecturer performance.

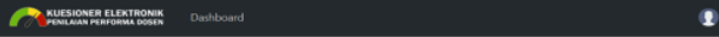

Lecturer Performance Questionnaire

\begin{tabular}{|c|c|c|c|}
\hline Lecturers & Course & Status & Editing \\
\hline Harson & Information & Filled & Re-edit \\
\hline $\begin{array}{l}\text { Kapoh } \\
\text { Stephy }\end{array}$ & $\begin{array}{l}\text { system } \\
\text { Program of }\end{array}$ & Filled & $\begin{array}{c}\text { Questionnaire } \\
\text { Re-edit }\end{array}$ \\
\hline Walukow & Algoritma & भined & Questionnaire \\
\hline $\begin{array}{l}\text { Tracy } \\
\text { Kereh }\end{array}$ & Maths & Filled & $\begin{array}{c}\text { Re-edit } \\
\text { Questionnaire }\end{array}$ \\
\hline Robby & Security & Not & Questionnaire \\
\hline
\end{tabular}

Fig. 5. Front page of students' access to lecturer performance evaluation.
The Figure 5 indicates the front page of students' access on lecturer performance form (questionnaire) where students can choose the name of lecturer and the course that the lecturer taught and the status whether the form has been filled or not. If students would like to change the appraisal they could make changes on edits icon available in the figure. Next is the lecturer performance evaluation form where students can choose their own departments, study programs, semester/class, course and the lecturer, and then they put score of their lecturer performance on 11 items. It can be seen on Figure 6 below.

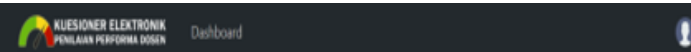

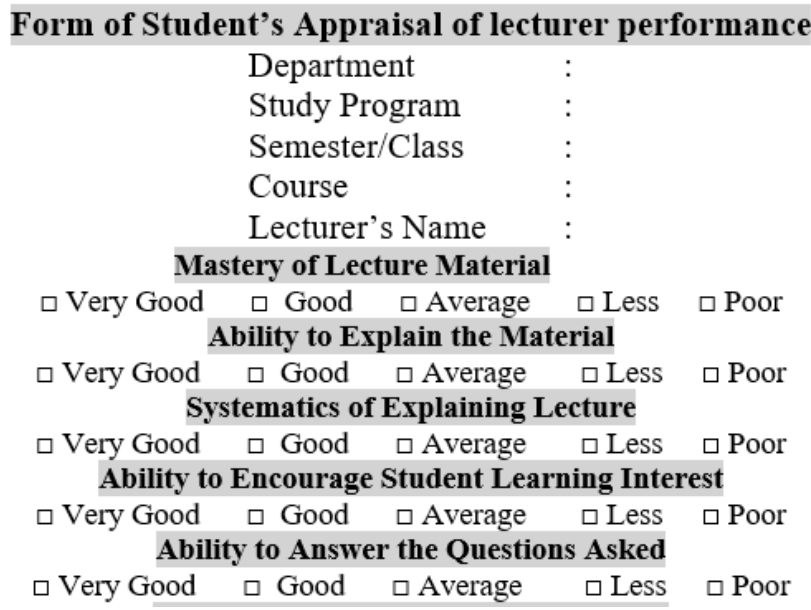

Fig. 6. The form of lecturer performance evaluation.

After filled in the form, the system will give an access of confirming the submission of the form. Students have to make confirmation whether the form has been submitted or not. Following is the Figure 7 where students can confirm the submission of the form.

\section{Thank you, the questionnaire successfully submitted}

Fig. 7. Confirmation of submitting the form.

4) Lecturer: Lecturer can also have a look the appraisal that students give. Following Figure 7 is the front page of dashboard of lecturer results where the lecturers can see the results of students' evaluation on their performance during one semester. It can be seen on Figure 8 below.

5) Head of department and study program coordinator: In conducting the student evaluation approach, some barriers are happened, such as the forms are not returned completely. Students are not seriously fill the form, therefore, it is difficult to judge the lecturer performance whether he/she performs well or not. 


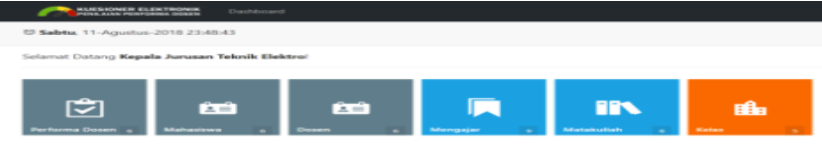

Fig. 8. The front page of dashboard of head of department.

After students filled the form, head of department and study program coordinator can access the results of the students' appraisal to all lecturers' performance by looking at to the recapitulation of the results made by the system. Following is the Figure 9 that shows the performance results of the student evaluation.

\begin{tabular}{|c|c|c|c|}
\hline 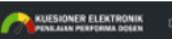 & & & 8. \\
\hline \multicolumn{4}{|c|}{ Results of Lecturer's Performance (T-I Study Program) } \\
\hline Lecturers' name & $\begin{array}{c}\text { Average } \\
\text { value }\end{array}$ & Total & \\
\hline Harson Kapoh & $46.67 / 55$ & 140 (3 results) & Check Detail \\
\hline Stephy Walukow & $34.47 / 55$ & 110 (3 results) & Check Detail \\
\hline Tracy Kereh & $50 / 55$ & 50 (1 result) & Check Detail \\
\hline Andritsu Polii & $32 / 55$ & 32 (1 result) & Check Detail \\
\hline Robby Lumbu & $36.5 / 55$ & 73 (2 results) & Check Detail \\
\hline Marike Kondoj & $0 / 55$ & 0 (0 result) & Check Detail \\
\hline
\end{tabular}

Fig. 9. The results of lecturers' performance.

\section{CONCLUSION}

In conclusion, student evaluation approach is one of evaluation approaches that can help this institution to improve its Human Resources, particularly, lecturers, which become the center point of learning process. Using student evaluation approach can assist the management of department and study program to evaluate their lecturer, so that they can be easily to make judgment for their lecturer for the future plan. In terms of using student evaluation approach, lecturers have to know well, what is the purpose of this evaluation, so that they will not resist about the results of evaluation. When these things do not happen, lecturer will be resistant of this kind of this evaluation and also the management of department and study program coordinator will not get the objective results of lecturer performance. Lecturers who have less performance have to give more attention so that Polytechnic Education will be more qualified comparing to other higher education institutions. Therefore, with using an application based online, it is recommended that the evaluation of lecturer performance might be objective and effective, because students can give their appraisal freely without the present of their lecturers.

\section{ACKNOWLEDGMENT}

We should thank Director of Manado State Polytechnic who is funding this research. We also thank the Head of Learning Centre and Quality Assurance, as well as Head of Department and Study Program Coordinators to participate in this research. We also thank the Head of Centre of Research and Community of Manado State Polytechnic for the encouragement in doing this research.

\section{REFERENCES}

[1] H.F. Hansen, "Educational Evaluation in Scandinavian Countries: Converging or Diverging Practices?," Scandinavian Journal of Educational Research, vol. 53, no. 1, pp. 71-87, 2009.

[2] D. Leite, R.A. Santiago, C.S. Sarrico, C.L. Leite, and M. Polidori, "Students' perceptions on the influence of institutional evaluation on universities," Assessment \& Evaluation in Higher Education, vol. 31, no. 6, pp. 625-638, 2006.

[3] Y.A.A. Liu, C.T. Tsai, J.S. Horng, and M.H. Lee, “An Initial Inquiry of Program Evaluation Framework for Tourism Higher Education in Taiwan," Journal of Teaching in Travel \& Tourism, vol. 10, no. 1, pp. 121, 2010.

[4] J. Välimaa and M. Mollis, "The social functions of evaluation in Argentine and Finnish higher education," Higher Education in Europe, vol. 29, no, 1, pp. 67-86, 2004.

[5] R. Macdonald, "The use of evaluation to improve practice in learning and teaching," Innovations in Education and Teaching International, vol. 43, no. 1, pp. 3-13, 2006.

[6] J. Ursin, M. Huusko, H. Aittola, U. Kiviniemi, and R. Muhonen, "Evaluation and Quality Assurance in Finnish and Italian Universities in the Bologna Process," Quality in Higher Education, vol. 14, no. 2, pp. 109-120, 2008

[7] B.P. Smith, "Student ratings of teaching effectiveness: An analysis of end-of-course faculty evaluations," College Student Journal, vol. 41, no. 4, pp. 788-800, 2007.

[8] C. Smith, "Building effectiveness in teaching through targeted evaluation and response: connecting evaluation to teaching improvement in higher education," Assessment \& Evaluation in Higher Education, vol. 33, no. 5, pp. 517-533, 2008.

[9] L.N. Wood and A. Harding, "Can you show you are a good lecturer?," International Journal of Mathematical Education in Science and Technology, vol. 38, no. 7, pp. 939-947, 2007.

[10] M. Huxham, P. Laybourn, S. Cairncross, M. Gray and N. Brown, "Collecting student feedback: a comparison of questionnaire and other methods," Assessment \& Evaluation in Higher Education, vol. 33, no. 6 , pp. 675-686, 2008.

[11] D. Kember, D.Y.P. Leung, and K.P.Kwan K P 2002 Does the Use of Student Feedback Questionnaires Improve the Overall Quality of Teaching? Assessment \& Evaluation in Higher Education, 2002, 27(5), 411-425.

[12] J.S. Pounder, “Transformational classroom leadership: a novel approach to evaluating classroom performance," Assessment \& Evaluation in Higher Education, vol. 33, no. 3, pp. 233-243, 2008

[13] A. Saroyan and C. Amundsen, "Evaluating University Teaching: Time to take stock," Assessment \& Evaluation in Higher Education, vol. 26 no. 4, pp. 341-353, 2001.

[14] K.J. Spencer and L.P. Schmelkin, "Student Perspectives on Teaching and its Evaluation," Assessment \& Evaluation in Higher Education, vol 27, no. 5, pp. 397-409, 2002.

[15] P. Spooren, D. Mortelmans and J. Denekens, "Student evaluation of teaching quality in higher education: development of an instrument based on 10 Likert-scales," Assessment \& Evaluation in Higher Education, vol. 32, no. 6, pp. 667-679, 2007.

[16] L.B. Nilson, Teaching at Its Best; A Research-Based Resource for College Instructors (3rd ed.). San Francisco, CA: Jossey-Bass, 2010.

[17] D. Bie and F. Meng, "On Student Evaluation of Teaching and Improvement of the Teaching Quality Assurance System at Higher Education Institutions," Chinese Education \& Society, vol. 42, no. 2, pp. 100-115, 2009.

[18] C. McCormack, "Re-conceptualizing student evaluation of teaching: an ethical framework for changing times," Assessment \& Evaluation in Higher Education, vol. 30, no. 5, pp. 463-476, 2005.

[19] Neumann R 2000 Communicating Student Evaluation of Teaching Results: Rating Interpretation Guides (RIGs). Assessment \& Evaluation in Higher Education, 25(2), 121-134.

[20] A.C. Worthington, "The Impact of Student Perceptions and Characteristics on Teaching Evaluations: A case study in finance 
education," Assessment \& Evaluation in Higher Education, vol. 27, no. 1, pp. 49-64, 2002.

[21] C. Yining and L.B. Hoshower, "Student Evaluation of Teaching Effectiveness: an assessment of student perception and motivation," Assessment \& Evaluation in Higher Education, vol. 28, no. 1, pp. 71-88, 2003 .
[22] T. Beran, C. Violato, D. Kline, and J. Frideres, "What do students consider useful about student ratings?," Assessment \& Evaluation in Higher Education, pp. 1-9, 2008.

[23] E.H. Cohen, "Student evaluations of course and teacher: factor analysis and SSA approaches," Assessment \& Evaluation in Higher Education, vol. 30, no. 2, pp. 123-138, 2005.

[24] N.K. Denzin and Y.S. Lincoln, Strategies of qualitative inquiry (3rd ed.) Los Angeles: Sage Publications, 2008. 